\title{
PROSPECTS AND CONSTRAINTS OF LOW-INTENSITY FARMING IN MARGINAL PERI-URBAN AREAS: THE CASE OF LESVOS, GREECE
}

\author{
Evangelos Pavlis, Theano S. Terkenli ${ }^{1}$
}

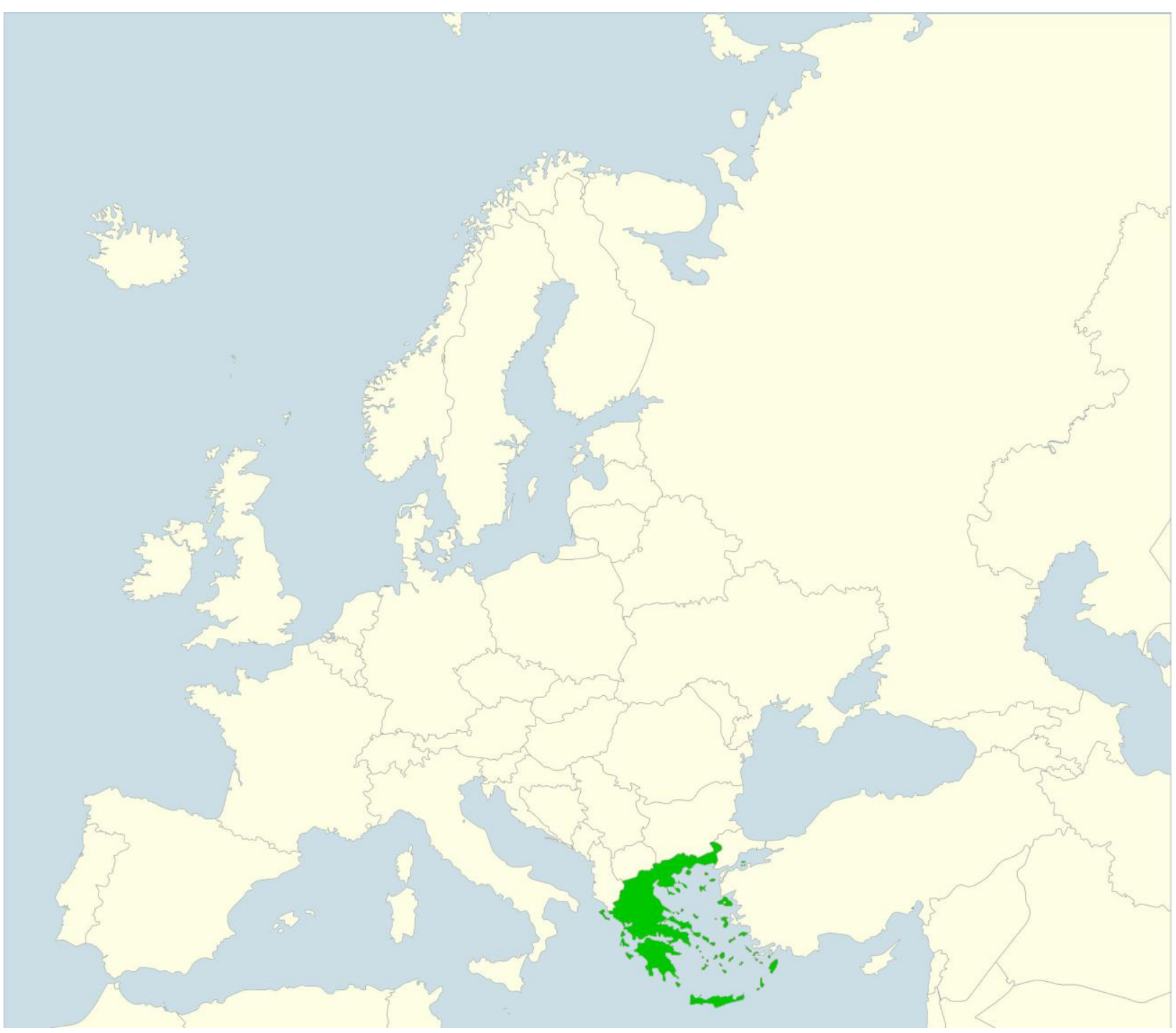

1 Evangelos Pavlis, post-doctoral researcher, e-mail: evan.pavlis@gmail.com, ORCID: 0000-0001-8210-541X; Professor Theano S. Terkenli, e-mail: terkenli@aegean.gr, ORCID: 0000-0001-6982-6132, University of the Aegean, Mytilene, Greece. 
Abstract: This paper critically examines the characteristics of low-intensity, small-scale family farming and related aspects of farming sustainability, in a marginally productive periurban landscape, that of the capital town of Lesvos Island, Mytilini, Greece. These aspects and characteristics are explored on the basis of farmers'-landowners' perceptions and visions of local landscape/land use change, through a questionnaire survey. Our findings indicate that production is basically aimed for self-consumption; such practices yield low incomes but bear high cultural values, mostly run by hobby and part-time farmers-landowners, lacking agricultural education. Olive crops are the dominant, but decreasing, form of production, while some other less-water-reliant cultivations are increasing. Peri-urban small family farming remains significant, but in need of new policies/strategies further promoting its value and role.

Key words: family farming; low-intensity; CAP subsidy schemes; agricultural production; selfconsumption; sustainability

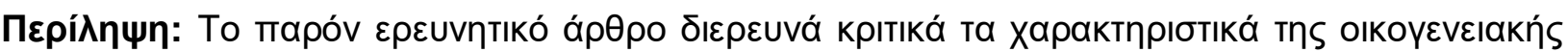

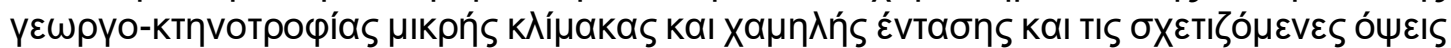

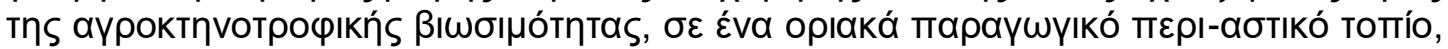

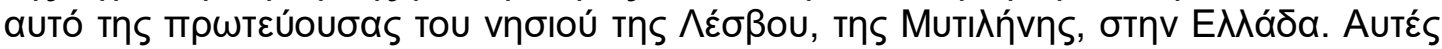

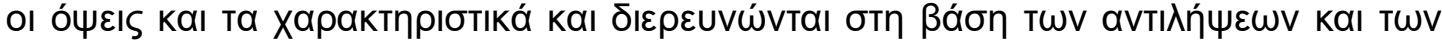

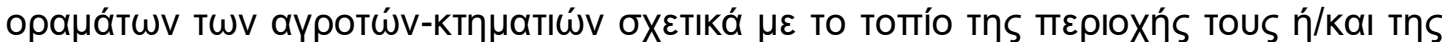

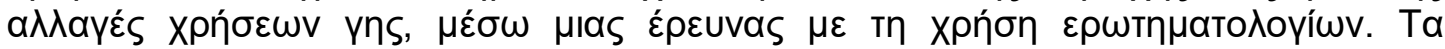

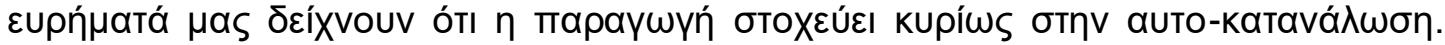

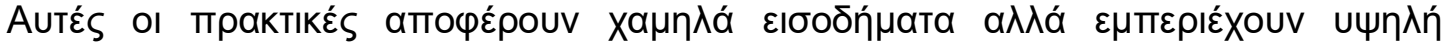

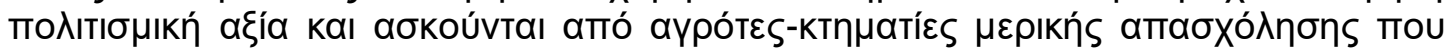

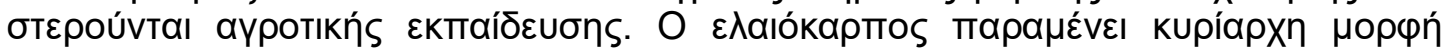

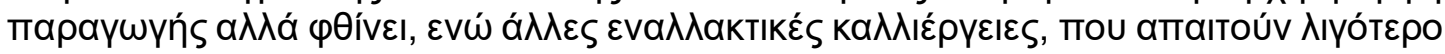

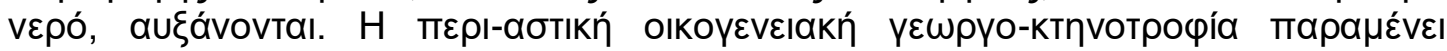

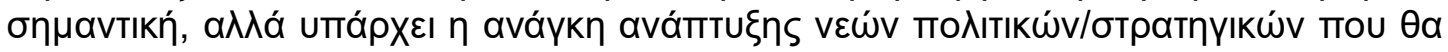

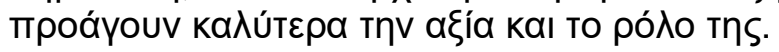

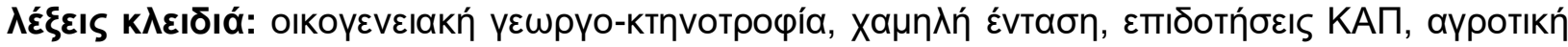

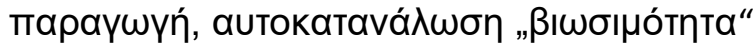

\section{Highlights:}

- Small-scale family farming geared towards low intensity production and self-consumption

- Farming characterized by low incomes, low economic dependency but high cultural values

- Motivation for subsidy scheme participation not strictly economic for non-full-time farmers

- Olive yield dominant but decreasing, cultivations with lower water requirements increasing

\section{Introduction}

Peri-urban agriculture is developing in the fringe of urban areas linking rural and urban areas around the globe. Peri-urban agriculture is defined as 'agriculture practices within and around cities which compete for resources (land, water, energy, labor) that could also serve other purposes to satisfy the requirements of the urban population' (FAO, 2015). Such land uses have been driven by a rise of a consumption-oriented society in a postmodern era of "flexible accumulation" of capital that has to be continuously reproduced and expended in innovative, exciting, creative and safe ways, in places suitable to live, visit, exploit, work, invest and consume (Park and Coppack, 1994, Hopkins, 1998; Luttik and van der Ploeg, 2004). Peri-urban agriculture differs from urban agriculture since the latter is integrated into the urban economic and ecological 
system, while the former links urban and rural areas (rural-urban continuum) shaping a dynamic 'intermediate space'.

Peri-urban areas are frequently characterized by multiple land uses for housing, farm services, energy consumption, recreation, education, and/or business purposes. Thus, they may include industries, theme parks, renewable energy enterprises, recreational and environmental farming, agro-tourism businesses (e.g., farm tourism, arts and crafts, guided tours), etc. (Zasada, 2011; Kasimis and Papadopoulos, 2013). They are associated with dynamic landscapes of social, technological and economic changes and with a significant number of various land-tenure conflicts (Dadashpoor and Ahani, 2019). Peri-urban areas may provide opportunities to commodify, diversify and re-evaluate farming production, to promote education, environmental conservation and recreation, to improve community relations and, in general, to restructure farming (Zasada, 2011; Russo et al, 2014).

Many peri-urban areas take advantage of such opportunities by developing family farming. This fact is especially observed in Mediterranean Europe, where land use change is becoming increasingly marginalized and restricted (Van der Sluis, 2016). After analyzing 80 papers published from 1985 to 2015, Debolini et al (2018) claimed that there are only a few case studies regarding family farming located in peri-urban inland and coastal regions in the Mediterranean Basin. The vast majority of farms in the EU are considered family farms (Peters, 2013). The significant role of family farming lies 'in eradicating hunger and poverty, providing food security and nutrition, improving livelihoods, managing natural resources, protecting the environment, and achieving sustainable development' for the farm-place (FAO, 2014b:4).

The objective of this study is to analyze and critically assess the most significant characteristics of low-intensity, small-scale family farming and related aspects of sustainability, in a marginally productive peri-urban landscape, namely the peri-urban area of the capital town of Mytilini, on Lesvos Island, Greece. We examined these aspects and characteristics on the basis of local perceptions on land use changes and future farming issues and concluded with a comparison of our questionnaire survey results with the present-day situation, with the aid of primary and secondary data.

\section{Family and small-scale farming}

The United Nations Food and Agriculture Organization (FAO) defines the family farm as 'an agricultural holding, which is managed and operated by a household and where farm labor is largely supplied by that household' (Hennessy, 2014:14). A family farm is 'any farm under family management where $50 \%$ or more of the regular agricultural labor force was provided by family workers' and $95.2 \%$ farms in the EU are classified as 'family farms' (Farm Structure Survey, 2016). FAO describes family farming as 'a means of organizing agricultural, forestry, fisheries, pastoral and aquaculture production, which is managed and operated by a family and predominantly reliant on family labor, including both women and men where the family and the farm are linked, co-evolve and combine economic, environmental, social and cultural functions' (FAO, 2014a:9).

The sustainability of family farming is not strictly a matter of production and labor, economy and profit, but it is also a matter of ecology, community and culture... enhancing all the pillars of sustainability: social, economic, ecological and cultural. Van Vliet et al (2015) claim that family farms sustain social cohesion, rural culture, farming community and rural landscape. Many of such farms tend to promote ecological agriculture, provide self-fulfillment and identity and achieve household food security (De Rosa et al, 2019; Inwood et al, 2013; Van der Ploeg, 2013). Van der Ploeg $(2013,2016)$ emphasizes the qualities of family farming by stressing: i) the control of the family over its main resources (buildings, machinery, crops, animals, know-how, etc.) so as "not to make a profit, but to make a living", ii) the provision of labor force in a place of selfemployment, iii) the nexus between the family and the farm, due to their interdependence, iv) the provision of income and self-produced food (and food security), v) the farm as a "home", as a place of livelihood and belonging, vi) the link between past, present and future, vii) the farm as a place for learning and knowledge building, viii) the farm as a part of a wider rural community 
and rural economy, ix) the significance of the farm as a carrier of cultural codes of local community and $x$ ) the farm as a part of a wider cultural landscape (and sustaining biodiversity).

The concept of family farming is often synonymous with small farms (FAO, 2015; Hennessy, 2014). There is no fixed definition of small farm. In general, small farms, thus, tend to be associated with small size, low income, self-consumption, limited resources, restricted economic viability, subsistence production and family farming (Guiomar et al, 2018; Hubbard, 2009). Adamopoulos and Restuccia (2014) used evidence of 167 countries and territories to emphasize the significance of small family farms which are responsible for a large share of the world's food production. They examined agricultural censuses of 63 countries and found that in the developed countries, farms with more than 20 ha occupy $70 \%$ of land, while in the developing countries, $70 \%$ of land is operated by farms sized less than 5 ha. Lowder et al (2016) claim that the average farm size in world's farms has increased globally in the developed world and decreased in the developing world. About $84 \%$ of the world's farms are smaller than 2 ha operating in about $12 \%$ of the world's land and about $90 \%$ of the world's farms are family farms operating on $75 \%$ of the world's land. The basic conclusion of Grain (2014) report is that the vast majority of world farms are small (and getting smaller), they produce most of the world's food being more productive than big farms and they operate on less than a quarter of world's farmland. According to the report, big farms use low levels of employment in order to maximize their return on investment, which translates into lower technical efficiency.

To focus on Europe, according to EUROSTAT and the Farm Structure Survey (2016), two-thirds $(65.5 \%)$ of agricultural holdings in the EU were less than 5 ha in size and their vast majority $(95.2 \%)$ were classified as family farms, with Malta and Romania featuring highest in this classification. In their comparative analysis of 25 regions in 15 European countries, Rivera et al (2020) show the importance of the contribution of small farms to regional production and food availability and suggest that this trend ought to be taken into consideration in policy making. Family and small-scale farming are important because they are linked to world food security, preserve agro-biodiversity and sustainable use of natural resources and support environmental, economic and social sustainability (Gliessman, 2014, 2015; De Longe et al, 2016; Galli et al, 2021).

\section{Marginal farming in the Eastern Mediterranean Europe and the case of Greece}

Traditional socio-agro ecosystems of Eastern Mediterranean Europe are an outcome of continuous cultural, social and technological change caused by the dynamic interaction between humans and nature, since the Neolithic Revolution. South Mediterranean Europe went through a period of economic depression, especially after the financial crisis in 2008 (Escribano, 2010), with direct impacts on agriculture and farming systems (Ortiz-Miranda et al, 2013). Moreover, the possible effects of climatic change to 2050 might result in lower farm net incomes in relation to Northern regions (Wolf et al, 2015; Gelfand et al, 2013). Several factors have been suggested to explain the continuous marginalization of farming, characterized by low food and feed crop productivity (Ciria et al, 2019), in Eastern Mediterranean Europe. Among those factors are structural, cultural and legal reasons, e.g., heritage systems resulting to segregation of land, land transfer regulations (Koutsou et al, 2011). Mountain areas and marginal regions of the Eastern Mediterranean Europe, mostly of High Nature Value, highly depend on retirement pensions and CAP (Common Agricultural Policy) subsidy schemes as the main sources of income (ArnalteAlegre and Ortiz-Miranda, 2013). The above characteristics constitute the "low-intensity traditional pathway" of Ingram et al (2013). Interestingly, Debolini et al (2018) showed that land abandonment is associated with intensification processes affecting annual crop production in the Mediterranean Basin.

According to a survey conducted by Pavlis et al (2016), respondents from peri-urban Northern European areas were more motivated to participate in Agri-Environmental Schemes than respondents from Central and Southern European areas with marginal potential for agriculture. Zasada et al (2018) emphasized the need to enhance regional targeting in rural development policies and to improve the consistency between funding distribution and the demands and 
requirements in regional level. Arnalte-Alegre and Ortiz-Miranda (2013:297) state that the 'agricultural and rural policies are designed mostly in the North'. However, they also suggest that rural areas in the Mediterranean formulate a cultural refuge, a site of community resistance to processes of socioeconomic change and a laboratory of ideas, symbols and meanings for the urban dwellers (Bunce, 1994). In other words, the nutritional diet of European agriculture is constructed, to a great extent, by ecological, structural, social and cultural elements of the Mediterranean, which is of special significance for rural societies in times of financial and economic crisis. A good example of marginal peri-urban landscapes of family farming can be found in Greece.

Since the 1990's, Greek agriculture seemed to be facing serious cultural, structural and economic problems. In Greece, family ties and networks still appear to be important for land property relationships. The survival of family agricultural holdings and the family model of farm production are significant characteristics of the Greek agricultural society (Nitsiakos, 1991; Zakopoulou, 2008). Family farming and landownership are directly linked due to the Greek inheritance system (remnants of a long agricultural past), according to which, land is bequeathed to the son(s) of the family and becomes segregated into smaller and smaller parcels of symbolic value, which often become abandoned. Koutsou et al (2011) stressed a problem with cultural roots since land is considered as a 'family asset' (passing from generation to generation, even if they do not live in the countryside) rather than a 'farming business'. In this cultural asset, landownership symbolizes 'roots' and 'identity'. The number of part-time and hobby farmers in Greece, generally speaking, is much higher than the number of full-time farmers and increasingly so, as farming in Greece is considered less as an occupation than a social and/or economic status (Vlahos \& Louloudis, 2011; Kizos and Vakoufaris, 2011). There are various cultural, structural and economic implications of these issues, impacting on family farm sustainability. Problems appeared as a result of the failure to restructure the agricultural economy (trapped for years in clientelistic politics) and of the 'increased costs of production, cutbacks in private investments, irrational management of EU funds, and ineffective structural policy' (Kasimis and Papadopoulos, 2013:278). Greek farm households depending upon agriculture are still characterized by a low income and a low standard of living (Karanikolas and Zografakis, 2008). However, Damianakos (2002:283) characterizes family farm in Greece as 'the sovereign principle of social organization of the village, forming the basis of society'. He supports that agricultural family has contributed to the economic and spatial reformation of agricultural areas in Greece, shaped by values of 'traditional' farming, offering a sense of culture and identity, and characterized by acknowledgement of land marginality, low-intensity, low inputs, debt, income diversification, family-centrism, environmental conservation and off-farm income. In recent years, small family farming still remains significant and contributes more or less to family sustenance.

\section{Presentation of the study area}

\subsection{The main characteristics of Lesvos' agriculture}

Lesvos is a northern Aegean island in Greece; it is the third in size island of Greece and forms one Municipality by itself. It represents a 'traditional' Mediterranean coastal-rural landscape of low-intensity family farming, slowly opening to small-scale tourism.

The island has been traditionally associated with agriculture, although during the past decade, farm labor has been reducing. The island - including our study area - has a strong potential for agriculture, facing challenges of accessibility, land abandonment, out migration of young people, limited profitability of on-farm activities and decrease of traditional production. Local agricultural activity focuses on olive cultivation as regards most of the island, except for a large part of Western Lesvos. Olive cultivation is characterized by terraces made in the distant past for construction purposes, revealing another dimension of the pre-industrial roots of the local rural culture and a distinct characteristic of Lesvos agricultural landscape (Terkenli et al, 2018). There are almost 80 oil presses in the island, of which nearly 55 are active. According to Northern Aegean Periphery and its Department of Agricultural Development, the reduction in olive oil production (approx. 2,000 tones per decade) seems to be largely due to the abandonment of olive 
farming, climatic conditions, olive tree diseases and other human-induced reasons (personal communication with the Director of the Unit, Georgios Lagoutaris).

There are internationally awarded olive oil family brands of extra virgin olive oil, revealing a local dynamism certified by over than thirty bottling plants operating in Lesvos. Despite this fact, according to the Department of Agricultural Development of Northern Aegean, only $20 \%$ of local olive oil is standardized, while the rest is sold in bulk often in non-Greek markets (e.g., Italy) (personal communication). The olive grove represents part of a strong regional identity of Lesvos being an integral part of collective agricultural heritage and history of the island. $80 \%$ of the olive variety "kolovi" is mainly found in Lesvos - the remainder is found in Chios and Skyros. The second most common variety is "adramitiani", originating from the region "Adramiti" in Asia Minor, covering $20 \%-30 \%$ of the olive grove. There are also some other varieties, such as "koroneiki, ladolia", etc. Nevertheless, producers do not reap the benefits of the specific quality of olive oil as the product is marketed in bulk at the price of conventional olive oil. In a good year, the percentage of extra virgin olive oil produced in the island may be around $50 \%$. A great part is kept for self-consumption and for distribution among friends and relatives and diaspora networks (often a small complementary small income), since olive oil is embedded in local gastronomy and culture and each farm household has its own olive oil. In fact, Mylonas (2015:1) stated that 'only 27 per cent of Greek production reaches the stage of labeling/branding, compared with 50 per cent in Spain and 80 per cent in Italy, with the remainder sold in bulk form, including 70 per cent of exports (mainly to Italy for re-export)'.

Mylonas (2015) also claims that Greece, along with Italy, achieves higher productivity in comparison to Spain and the extra virgin olive oil regards $80 \%$ of the production in Greece (best quality), while for Italy it accounts for $65 \%$ and $30 \%$ for Spain. However, problems of quality, apart from the crop itself, have been witnessed in each of the levels of olive oil production procedure; primary production (olive collection), processing (oil mill pressing), standardization, marketplace distribution and marketing. There are no significant differences in the prices of industrial and virgin olive oils and many producers claim that the incentives are not enough for the production of quality olive oil. In general, there are basic structural, cultural, natural and economic reasons with a significant negative impact on the development of the local agricultural economy.

\subsection{Lesvos landscape and the study area}

The study area is the peri-urban area of Mytilini and its surrounding Peninsula of Amali occupying the southeastern part of Lesvos Island shown in Figure 1. Mytilini is a typical midsize town of a Greek Northern Aegean island.

The landscape of Mytilini (or Mytilene) consists of a multiform terrain of littoral/coastal, lowlands, hilly areas and uplands, a rich variety of ecosystems and ecological reserves, fossil and volcanic sites, hot springs, a variety of species of flora and fauna, along with the continuous human impact on the environment since prehistoric times, ancient, Byzantine and more recent 'traditional' or contemporary monuments, fishing harbours and coves, marine sports amenities, castles, churches and monasteries, a network of trails, swimming beaches, etc. The island of Lesvos as a whole has been designated as a 'UNESCO Global Geopark'.

The study area is considered as a peri-urban and urban marginal area; marginal in terms of GDP (one of the lowest in EU-28), in terms of tourism and agricultural development (i.e., lack of a comprehensive action strategy and integrated approaches). Agriculture, and especially olive cultivation, has traditionally been the main land use in this part, while a large proportion of the population also deals in wholesale and retail trade, fishing, construction, public administration and tourism service provision.

The study area includes a mix of land uses: villages, farming land, forest, bare land, quarries, industrial, wholesale/ manufactural, business, sports, leisure and public administration sites. It serves as a transport hub, hosting the eastern harbor and the only airport of the island. 


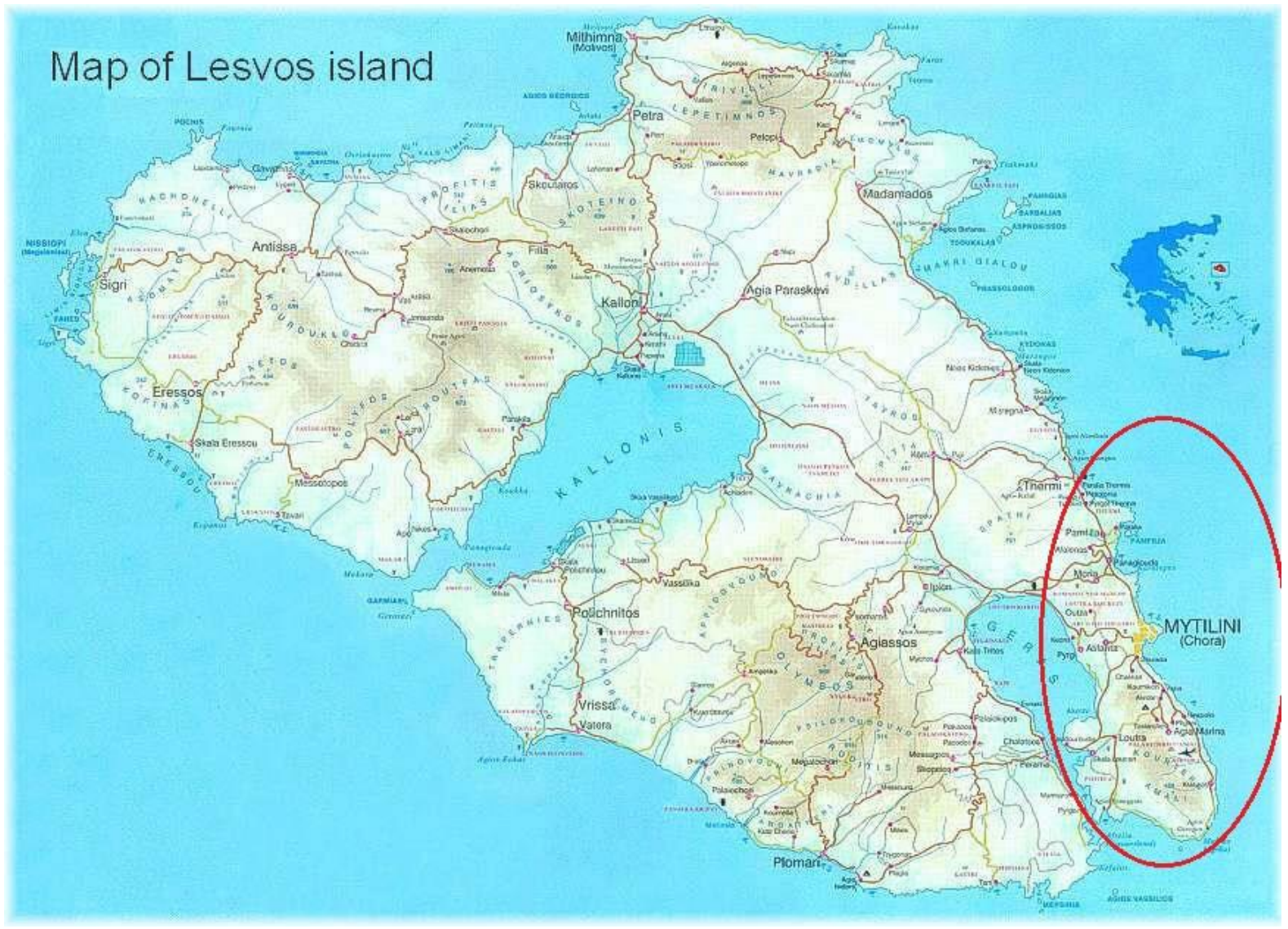

Fig 1. Map of Lesvos Island and the study area. Source: https://modeoflife.wordpress.com/ (processed by the authors)

\section{The method}

Our methodological approach involved a structured questionnaire survey and participant observation, in order to access fully rural landowners' perspectives on agricultural production, in terms of property characteristics, economic activities, time and employment, agricultural production on property and knowledge and use of subsidy schemes. For this study, landowners were categorized according to their self-reported engagement in farming (100\% full-time, 50-99\% part-time, $1-49 \%$ hobby farmer, $0 \%$ non-farmer). Our usage of the term 'farming' includes all rural income-earning activities (including livestock raising, bee-keeping and other). This research was undertaken as a case study in the context of a broader EU FP7 research project on Visions of Land use Transitions in Europe (VOLANTE) aimed at developing a model plan and designing a roadmap for future land resource management in Europe.

The collection of data began with the aid of a structured questionnaire survey, during the period February-May 2012, with a sample of 90 landowners. The respondents were selected with a simple random sampling and snowballing methods. Due to the lack of a landowner's archive and of a land cadaster for our case study area, we used the municipal poll catalogue. Drawing lots were carried out by a research randomizer (http://randomizer.org). The sample included 45 respondents from the city of Mytilini (urban residents), and 45 respondents from the ten rural villages (all in a distance up to $10 \mathrm{~km}$ from the capital) in our case study area: Pirgi Thermis, Pamfila, Panagiouda, Afalonas, Moria, Alifanta, Taxiarches, Agia Marina and Loutra. Urban interviews were carried out in the Vice-Mayor's office with a simple random sampling method (statistically random). Rural interviews took place in local Council Halls; local councilors helped to build trust between the interviewers and the interviewees. In some villages, snowballing methods were used (i.e., participating landowners or local councilors identified additional potential respondents) due to the smaller number of village residents. Landowner personal and property characteristics, such as size and acquisition, which may have influenced our survey participants' responses, were also taken in consideration (Kristensen et al, 2015). 
The questionnaire focused on economic activities and employment, agricultural production and implementation of EU Argi-Environmental policies. Specifically, the questions regarded:

a) Property characteristics (size, acquisition, planned succession)

b) Economic activities (income source)

c) Time and employment (time spent in agricultural activities, influence of certain factors on the ability to provide products or services - either strong positive to strong negative influence on ability to provide this service/product by using Likert scale)

d) Agricultural structures and production on property (land renting/ renting out, land use and livestock on farm, percentage of production for one's own consumption, level of engagement in farming, description of the activity level of the farm, intensity of land use, farm certification, buildings used for non-agricultural activities in the past 10 years)

e) Knowledge about the use of subsidy schemes (type of subsidy reception, type of landscape/ land use change, as a response to the subsidy, main reasons/ motives for using or not using the subsidy schemes)

f) Biographical information (name, age, marital status, education, etc.)

A final open-ended question regarded the survey participants' perceptions on land use changes, future farming issues and their future landscape vision. They were also invited to offer any additional comments on the previous questions. Participant observation was carried out throughout this research and regarded the collection of primary and secondary data through observation, available statistical data on present-day situation and involvement with the local residents in their local landscape contexts.

We used a chi-square test to determine the significance level of statistical relationships between selected variables and the use of subsidy scheme. Cross-tabulations were conducted with SPSS, a significant level of $95 \%$, and a p value lower than $0.05(5 \%)$.

\section{Results}

The sample of 90 respondents came out of a sample that shared the following characteristics:

a) Not direct economically dependency on farming (hobby farmers or non-farmers)

b) Farm ownership for three generations

c) Ownership of very small properties (less than 1 ha for the majority)

d) Acquisition of property because it was a good place for farming

e) Lack of an agricultural educational background (98\%)

f) Membership of agricultural associations/ co-partnerships (64\%)

g) $23 \%$ employs non-family workers (often with family workers)

h) $10 \%$ of the respondents are organic farmers

i) $75 \%$ of the respondents grew up in the countryside

j) $70 \%$ of the respondents produce food for the needs of their own consumption

\subsection{Farming engagement and sources of household income}

Our survey revealed that most of the respondents (68\%) were largely landowners practicing hobby farming and non-farmers, shown in Figure 2. The different categories of farming engagement are explained in the previous section of the paper and were developed on the basis of the respondents' self-reported time spent on farming activities. Little time was spent on agricultural activities since, on average, respondents declared that they spent $25 \%$ of their time in agricultural activities, a fact that categorizes them as 'hobby farmers' (1-49\% hobby farmer) according to the categories of the present study mentioned in the previous section. 


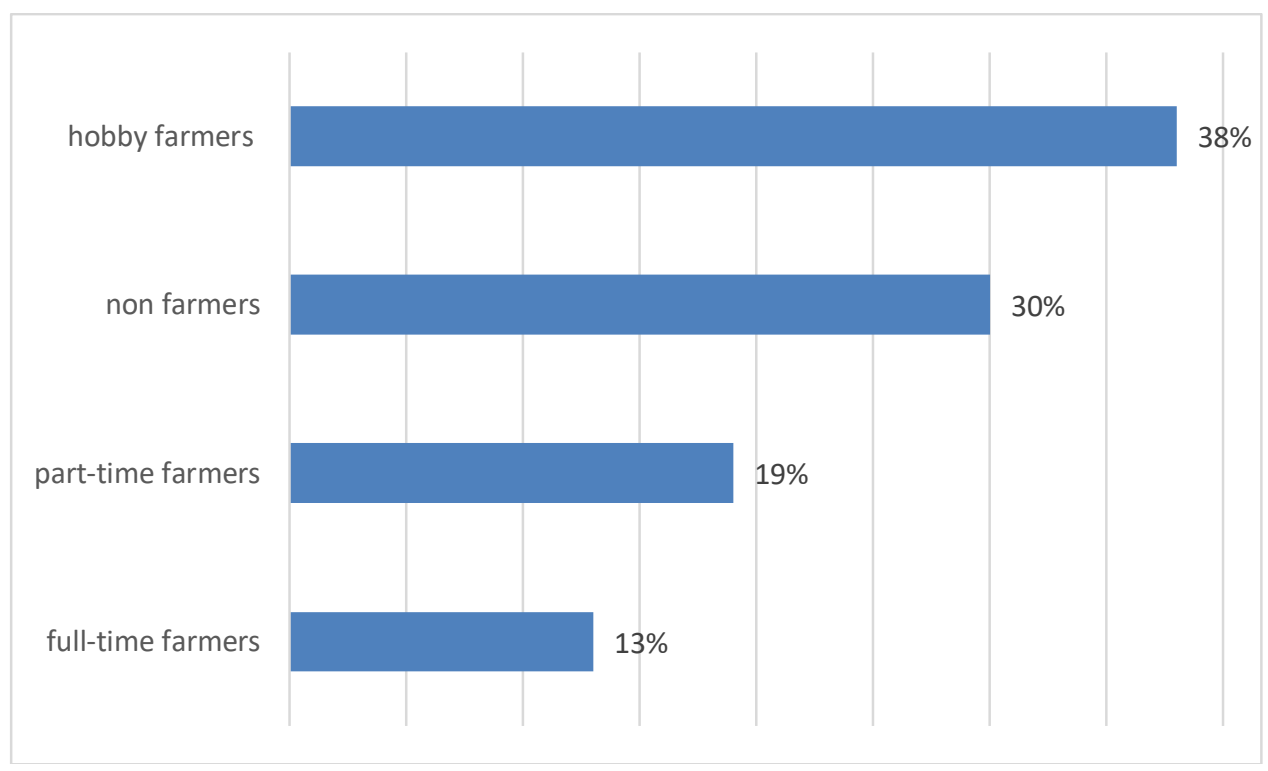

Fig 2. Landowners' farming engagement. Source: Own source and elaboration

Figure 3 shows the percentage of the answers related to each category of farm household income source (with more than one answer acceptable). It is evident that most of the answers regard offfarm income and that only half of the farm households seem to be gaining some income from the farm. Half of the respondents reported that they gained some income from peri-urban family farming, such as the direct sale or share of some agricultural products (oil, fruits and vegetables, meat, milk, eggs, etc.) in bulk (direct sale to local olive oil industries or via friends and relatives' networks). However, this income was reported to be very low, and specifically $5-10 \%$ of their total household income, in a case study of mainly lower-middle-class people, at one of the lowest GDP areas of the EU (ESPON, 2010). It was estimated at less than 600 euros per year for a mid-size farm, and came from the direct sale of agricultural products, combined with CAP subsidy scheme funding. Due to the limited profitability of farming activities, local households do not seem to be able to make a living without off-farm income (working as civil servants, self-employed, etc.).

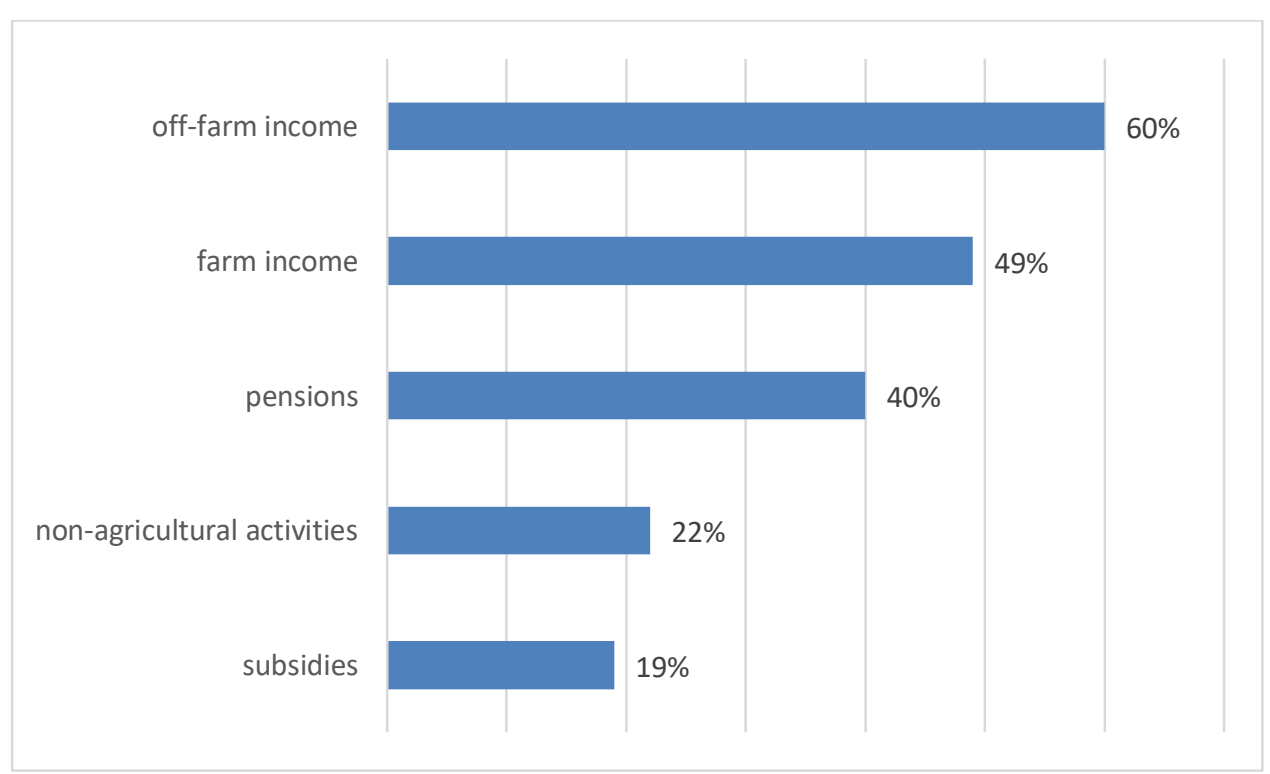

Fig 3. Sources of respondents' household income. Source: Own source and elaboration

Table 1 shows the same categories of household income sources, by landowner type. Full-time farmers, as expected, seemed to depend mostly on farm income and pensions (for retired farmers), and not on subsidy scheme ( $83 \%$ of them). Part-time farmers, as also expected, said that they derived their income from farm and/or off-farm labor (including pensions and 
participation in subsidy schemes) but not from non-agricultural activities on the farm in their agricultural property (apart from olive farming). Interestingly, hobby farmers appeared to be the most flexible category of all, deriving their income from a variety of sources, typical of the pluriactivity of hobby-farm households. Some of them declared that they were into nonagricultural activities, such as house-for-rent schemes or agro-tourism. Non farmers, as expected, mostly seemed to depend on off-farm income sources (including pensions), while one-third of them responded that they depended on non-agricultural activities and fewer than one-third on farm income. In such cases of indirect engagement with the land, the landowners of our sample tended to rent their land out to farmers, in exchange for some share of the crops and livestock with little economic profit from it (a practice called "kesimia" in the local dialect).

Tab 1. Significant sources of household income by landowner type. Source: Own source and elaboration

\begin{tabular}{|l|r|r|r|r||r|}
\hline \multicolumn{1}{|c|}{ INCOME TYPE } & $\begin{array}{c}\text { FULL- } \\
\text { TIME }\end{array}$ & $\begin{array}{c}\text { PART- } \\
\text { TIME }\end{array}$ & HOBBY & $\begin{array}{c}\text { NOT A } \\
\text { FARMER }\end{array}$ & $\begin{array}{c}\text { NO. OF } \\
\text { ANSWERS }\end{array}$ \\
\hline Farm income & 9 & 12 & 15 & 8 & 44 \\
\hline Non-agricultural activities & 1 & 0 & 10 & 9 & 20 \\
\hline Off-farm income & 3 & 12 & 20 & 19 & 54 \\
\hline Pensions & 7 & 6 & 18 & 5 & 36 \\
\hline Subsidy scheme & 2 & 5 & 8 & 2 & 17 \\
\hline Total & 22 & 35 & 71 & 43 & \\
\hline
\end{tabular}

One of the respondents dealing with non-agricultural activities, supported by rural development programmes, characteristically said: "If somebody doesn't own capital, he/she could be forced to abandon the program/ scheme". There is a need for better information on such schemes "by successful entrepreneurs and not by office people", as one of them claimed. In our sample, more than half of the full-time farmers we interviewed were retirees (economically reliant on pensions). World competition does not take account of production costs, which are high in Lesvos, as compared to other olive-oil producer areas of Greece and even more so to other olive oil producer countries (Spain, Portugal and Italy) (Kizos and Koulouri, 2006; deGraaf et al, 2008; Mylonas, 2015). Hence, farming in Greece has been turning into a side activity, rather than as a main one, although Lesvos is considered to be a predominately rural island (OECD urban-rural classification, EDORA database, 2010). Our case study area is found to be characterized by "traditional" farms of low farm income with low economic dependency on farming. Peri-urban farming seemed to be marginal while there was not any special diversification of their farming activities observed (Figure 3, Table 1).

\subsection{Characteristics of agricultural production}

Production in the study area was declared to be decreasing during the past 10 years (20022012). In terms of the crop yield, although only $1 / 5$ of the sample responded to this particular question (probably because they were not the main managers of the land or because of the lack of trust between respondent-researcher, regarding the use of the results of the survey), more than half of the respondents witnessed a decrease, as it appears in Table 2. In many cases, farm production was found to be tailored to the needs of one's own consumption. Almost $60 \%$ of the crops (mainly olives) and more than $80 \%$ of livestock (sheep, goats and poultry) was declared to be intended for one's own consumption. No energy crops (bioenergy) were reported, apart from olivewood for one's own consumption. Our results have also shown that the higher the farm engagement observed also meant the higher the propensity for the farm to engage also in livestock raising.

The respondents who used pesticides appeared to be few. $36 \%$ answered that they make no use of pesticides (nearly half of them were hobby farmers). Those that were more prone to pesticide use $(p=0.001)$ were the landowners of larger farms (over 10ha), with nearly half of them to be hobby farmers. 
Tab 2. Parameters of farm (or cultivated land) intensification between 2002 and 2012. Source: Own source and elaboration

\begin{tabular}{|c|c|c|c|c|c|c|c|c|c|c|}
\hline & Increase & $\%$ & Decrease & $\%$ & Unchanged & $\%$ & No use & $\%$ & Respondents & $\%$ \\
\hline Nitrogen use & 3 & 4 & 14 & 19 & 33 & 46 & 22 & 30 & 72 & 80 \\
\hline Pesticide use & 3 & 4 & 7 & 10 & 36 & 50 & 26 & 36 & 72 & 80 \\
\hline Stocking rate & 14 & 18 & 7 & 9 & 12 & 15 & 46 & 58 & 79 & 88 \\
\hline Crop yield & 4 & 22 & 10 & 55 & 4 & 22 & & & 18 & 20 \\
\hline
\end{tabular}

Generally speaking, the olive groves were managed with limited chemical inputs in a relatively semi-natural olive grove ecosystem/ environment, but the crop yields were rather decreasing. Nitrogen is an important nutrient for plant growth; its value and use, in certain amounts, is known to raise with crop productivity, whereas its excessive use affects crop maturing negatively. The tendency for nitrogen use reduction is considerable and mostly by people with ages over 40 years old $(p=0.048)$ (Table 3$)$. Nearly half of the respondents $(42 \%)$ were involved in stockbreeding, a number that has been increasing during 2002-2012. Stock-breeding appeared to be and applied more to hobby farming for self-consumption needs.

Production has been reported as more or less stable. A propos, some respondents declared: "a potential change of land cover/ use would involve a lot of risk", "few young people are interested in farming", "not worth it to buy food for productive animals, it is better to grow your own", "there is lack of information, expert guidance and agricultural education", "the producer price of olive oil in Greece is very low, in relation to labor and sustenance costs... for example, it costs $1.60 €$ per liter, while in Turkey it costs $3.10 €$ per It", and "there is no organized support for private initiatives; rather, discouragement prevails". Some respondents emphasized the difficulties posed to farming of the sloping ground of Lesvos, the abandonment of (inaccessible) upland olive groves, the shortage of irrigation water (only one water dam, and very few and small rivers and lakes), the long distances of farms from the main houses, the economic crisis and the inability to sell their products in new markets at good prices. They postulated that farming systems dominated by olive cultivation do not lead to the desirable goal, which is either self-consumption or/ and extra income, adding that there does not seem to be an alternative, since "we cannot remove our olive trees without any prospect or help from the State". As a result, it seems that in our case study farm production has been restricted to covering the needs of its own consumption.

\subsection{Factors influencing local production}

As Table 3 shows, family/ local traditions appeared to be the incentive influencing the most the landowners' ability to provide products or services, something which testifies cultural roots, identity and characteristics of family farming that contribute to the sustenance of rural culture, rural landscape and the farming community (Van Vliet et al, 2015). Human and physical geographical factors such as proximity to cities or transport facilities and soil/ climatic conditions seemed to influence local landowners to produce and place their agricultural products (more apparent in the countryside for obvious reasons), and especially olive oil, since such factors directly apply and impact on the availability and the quality of the product placed in the market.

Respondents claimed that they had mainly been consulted in their practices by family, friends, old experienced farmers "who lived in the fields", agriculturists and expert entrepreneur consultants (for obvious reasons, such as experience, knowledge, expertise respectively), who tend to be the main consultants of all farmer types locally. A respondent characteristically said that: "During the past, there was only one agriculturist with a single bicycle cycling all over the island to consult with the farmers. Now, there are many agriculturists doing paper work"'. This seemed to be the dominant opinion of both full-time and part-time/ hobby farmers, along with their perceived lack of State support. 
Tab 3. Factors influencing landowners' ability to provide products or services. Source: Own source and elaboration

\begin{tabular}{|l|r|r|l|r|}
\hline & frequency & \% & $\begin{array}{l}\text { strong positive influence } \\
\text { on farming production/ } \\
\text { rural services }\end{array}$ & $\%$ \\
\hline Personal education & 19 & 6 & 5 & 5 \\
\hline Personal network & 43 & 13 & 12 & 13 \\
\hline Family/ local traditions & 77 & 23 & 23 & 24 \\
\hline Access to financial capital & 40 & 12 & 16 & 17 \\
\hline Proximity to cities/ transport facilities & 60 & 18 & 11 & 12 \\
\hline Ecological factors & 47 & 14 & 13 & 14 \\
\hline Soil/ climate conditions & 55 & 16 & 15 & 16 \\
\hline TOTAL & 341 & & 95 & \\
\hline
\end{tabular}

\subsection{Use of subsidy schemes}

A third of our respondents (32\%) declared that they were motivated to participate in EU subsidy schemes not strictly by economic motives. The latter findings reveal a variety of more-thaneconomic motives, associated not only with the environment, biodiversity, and the landscape, but also with local community networks and landowners' self-esteem (e.g., learning new skills, selfchallenges, professional pride, moral/ ethical motives). During the time of the survey, participation in subsidy schemes favored larger farms and higher levels of farming engagement in our case study area. Those who did not participate in subsidy schemes claimed that they decided to do so because they lacked eligible areas for participation in subsidy schemes or because they had small farm areas on which they could not spare land for such schemes (Figure 4).

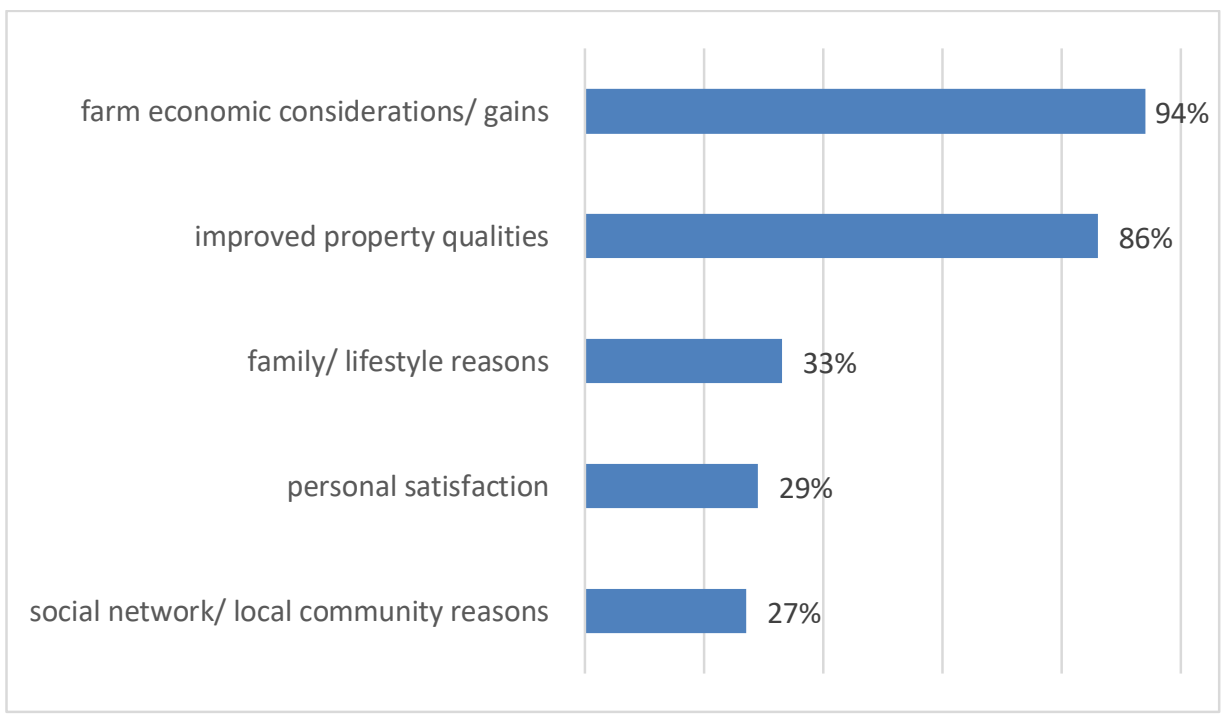

Fig 4. Reasons for participation in subsidy schemes. Source: Own source and elaboration

Most of the respondents that used subsidy schemes declared the use of CAP Pillar I subsidy scheme (21\%) and particularly the subsidy scheme for olive grove acreage or area and olive oil quality. The other landowners that used subsidy schemes reported the use of CAP Pillar II subsidy scheme $(11 \%)$, and specifically the subsidy scheme for organic farming $(9 \%)$, stock-breeding $(1 \%)$ and farm equipment machinery (1\%).

During the years 2007-2013, the rural development policy for Greece was implemented through the EU Rural Development Programme 2007-2013 (RDP) focusing on synergetic Pillars. The first Pillar aiming at the "Improvement of the Competitiveness of the Agricultural and Forestry Sector", included subsidy scheme for quantity of olive oil production and subsidy per stemma (0.1) as well 
as measures aimed at the support of young farmers or farm succession. This subsidy scheme constitutes low financial support (less than 200 euros per year for a midsize olive farm) and they usually do not contribute much to the household income (which is probably the reason why several respondents did not even mention them). It has been noted that the landowners participating in such subsidy scheme (strictly by farm size) do not aim at olive production. Landowners participating in CAP Pillar I subsidy scheme stated that they were motivated by farm economic considerations and gains in order to seek the economic benefit of the subsidy (so as to increase their farm income), but they also stated that they did so in order to improve property qualities, too (i.e., aesthetic and environmental improvements). CAP Pillar II subsidy scheme mainly involved organic farming. It is observed that the use of particular subsidy scheme grew proportionally with the size of property and with the level of engagement in farming, since half of the respondents using such scheme were full-time farmers and the participation of part-time farmers was lower, whereas the participation of hobby and non- farmers was even lower. However, no statistically significant results can be drawn here, because of our small sample size (10 out of 90 respondents).

In their additional comments, respondents mentioned that the most important step to increase support of subsidy schemes, especially of CAP Pillar I and II, was "proper and integrated information, advising and consulting".

\subsection{Future farming and landscape vision}

According to respondents' opinions vis-a-vis the open-ended question regarding future farming and their landscape vision, the number of part-time and hobby farmers along with the "production for self-consumption' trend (self-consumption agriculture) is expected to grow couple of decades in the future. This is expected to take place in the lowland area, while the abandonment of the uplands would continue. However, respondents talked about limited land use changes. They also foresaw that there would be an increase in vegetables, other cultivations (with no specification) and stock-raising units and that the olive tree would remain the dominant ecosystem: "Olive trees, small-range farms and small gardens...even on their balconies", "olive groves, permanent crops...the crop type won't change", "there will be no big changes... perhaps some cultivations will be more organized and some pastoral units more productive". Some argued that "there will be fewer but more educated professional farmers. Part-time farmers and nonfarmers owning rural property will not be actively involved and they will sell their property." On the contrary, another respondent argued that: "Today, young people are not involved in farming. There are no professional farmers on the island who can make their living exclusively from farming". Further opinions offered were: "We will get over intermediaries. Producers shall also become traders. We will return back to co-operations", and finally, it was emphasized that new technologies "for permanent crops, machines for olive collection will be very widespread".

They also referred to the need for more efficient local subsidy scheme management and encouragement of young peoples' involvement in agriculture. In general, they referred to the need for encouragement of private initiative, protection of flora and fauna from diseases, opening up to new markets, better-adaptable CAP terms and conditions (e.g., based on production and cost, instead of farm size), reasonable prices of fodder and farm machinery, and for an improved farmer-State relationship, based on mutual trust and more efficient taxation.

Their landscape vision could be summarized as a cleaner, greener, more pleasant landscape, characterized by modernized means of production and sustainable management of natural resources. Some of their key words were: "rural, open, green and clean landscape", "other cultivations/ crops", "more crops in rural properties...e.g., aromatic plants", "olive oil, cheese, small enterprises-cooperatives (stockbreeding-agritourism)", "development of more crops and cultivations...self-sufficiency". Specifically, in their answers, there was a reported trend towards a more organized and mechanized agriculture with fewer intermediaries, innovative and collaborating networks of producers, with more informed, younger, motivated, and agriculturallyeducated/ trained landowners. To succeed in that, in their answers, they emphasized the need for new State motives for agricultural development, higher landowner engagement with the land and imposition of clean environment policies. 


\section{Discussion}

\subsection{The peri-urban landscape of Lesvos}

The peri-urban landscape of our case study area in Lesvos, as in many other Mediterranean areas, is characterized by low-input (Douma et al, 2016) and low-intensity (Van der Sluis et al, 2016) small-scale family farms, facing many economic, social, cultural, technological and political challenges. Such farming systems are significant for their natural and cultural values in marginal areas of the Mediterranean Europe. Although, peri-urban farms are dynamic landscapes of multiple land uses and also much adaptable to restructuring and social, technological and economic change (Zasada, 2011; Russo et al, 2014), the farms of our case study seemed to be highly dependent on cultural factors (Table 3; see also Kizos and Vakoufaris, 2011), providing the link between past, present and future, in the context of their cultural landscapes (Van der Ploeg, 2013; 2016). Obviously, the capital town of Lesvos, Mytilene, is a mid-sized island city that cannot be described in terms of a large urban center, such as Athens, Thessaloniki or Patra, in mainland Greece.

Family farms are small in size and getting smaller (following the global trend; Grain, 2014), in contrast to the trend of farm size growth in the developed world (Lowder et al, 2016). They are mostly run by hobby farmers and family labor. Hobby farms of our case study tend to be more pluriactive in terms of the variety of income sources, as would be obvious. $77 \%$ of the total farm workforce is provided only by family members and the rest is shared by a combination of family and non-family seasonal labor. Family farms' production is mainly intended for self-consumption. This trend is confirmed by the number of workdays of non-family workers on agricultural holdings in Lesvos, who provide for $13 \%$ of the total labor needed on an agricultural holding, a figure that is lower than the national average of $18 \%$ (Hellenic Statistical Authority, 2016). This number is also lower than the corresponding EU figure $(93 \%$ of EU farms operate only with family workers, Farm Structure Survey, 2016), perhaps, due to the need for farm conservation and especially to local production needs in conjunction with off-farm sources of income. In terms of the trend of smaller farms to produce more due to the use of laborers of higher technical efficiency (Grain, 2014), the respondents of our survey also reported that local landowners-farmers of smaller farms tended to hire laborers with good technical skills, for purposes of farm and crop quality control. This tactic had been more widespread until the end of the $20^{\text {th }}$ century, and is now beginning to fade. According to the last available source of statistical data (Hellenic Statistical Authority, 2009), the percentage of mutual assistance workers and piece-rate workers out of the total number is $17 \%$ (counting them as one variable) for Lesvos. Local farms are subsistence-oriented and few of them have diversified out of traditional olive production. They are non-diversified farms of limited chemical inputs, not suited to mechanization, based on natural methods of farming, run by landowner-farmers with low engagement in farming activities. They do not aim for profit but for self-consumption and for distribution in friends and relatives' and diaspora networks and also aim to sustain rural culture, farming communities and the rural landscape (Van der Ploeg, 2013; 2016; Van Vliet et al, 2015).

They are characterized by many of the qualities of family farming (Van der Ploeg, 2013, 2016) and specifically by (very) low on-farm income, low (or non-) economic dependency on farming and mainly off-farm sources of income (Giourga et al, 2008). Farm diversification and off-farm employment are more common than full-time farming in all of our research sites, which represent marginally productive peri-urban agricultural areas, basically run by landowners-farmers. The Lesvos farm development "pathway" is a small-scale, traditional, family-held, low profitability, low-intensity and self-consumption farm of high cultural value that leads to a rather stable landscape. The landscape vision of our respondents seemed to have been directed towards selfsufficiency, modernization of farming methods, agricultural education and other cultivations.

The peri-urban landscapes of Lesvos are shaped mostly by family/ local traditions (i.e., empirical knowledge of old-time methods, techniques of production and land management) and by a lack of agricultural and entrepreneurial education, integrated information, consulting and expert knowledge, as well as State care and provision. According to our interview responses, agricultural education does not seem to play a significant role in agricultural production and provision of agricultural services. There is also a need for building more satisfactory citizen - State 
relationships (trust recovery to the State and EU), which seem to have deteriorated after the financial and national-debt crisis. These facts are perhaps indicative of the trend in local entrepreneurship, which is, more or less, based on empirical knowledge, on old-time methods and techniques, and on family/ local traditions. Such trend often denotes limitations in promotion, marketing, quality and product diversification and indicative of the total lack of agricultural education in Greece, since farming had not been considered as an occupational status until 2010, as explained above.

In general, land use change types are highly diverse among member-states and depend on local and national contexts. Perhaps "one-size fits-all" policies and regulations ought to be reconsidered, as they tend to be difficult to adapt indiscriminately by all local landscapes and landowners (Vesterager et al, 2016). Environmental, agricultural and other policies regulating land use ought to respond better to local socio-economic conditions, in order to gain traction.

\subsection{Local production characteristics and distribution channels}

Traditional family farming in Lesvos aims towards self-consumption for health and cultural reasons (Kizos and Vakoufaris, 2011; Van Vliet et al, 2015) and towards the continuation of 'traditional' ways and farming values (Van der Ploeg, 2013; 2016; Ingram et al, 2013). Such farming practices confirm that land in peri-urban Lesvos is considered as a family asset rather than a farming business (Koutsou et al, 2011) and is practiced mainly by landowners/ farmers not economically dependent on farming. In fact, the dependence of the island's agriculture on the world market is high, since olive cultivation constitutes the dominant farming system and, after considering the frequent fall of olive prices, it is doubtful whether farmers (especially as individuals) can make their income from farming without satisfactory additional off-farm support. Van der Sluis et al (2014) observe that the number of farmers is decreasing in Lesvos.

This survey shows that nearly half of the respondents were involved in stock-breeding (an increasing trend during the period 2002-2012), while nearly all respondents were involved in olive oil production (a decreasing trend for the same time period). These trends stand in contrast to the increase of the share of farms specializing in crop production in the EU and in many Mediterranean countries (including Greece) and the decrease of the share of mixed farms during the period from 2005 to 2016 (Farm Structure Survey, 2016), due, perhaps, to the fact that these tend to be different types of economies.

As expected, respondents were mostly involved in the direct sale or share of some agricultural products in bulk. Sales in bulk mean loss of added value, since olive oil, the emblematic product of such family farms, in such a peri-urban family farm context is also a socio-cultural, a symbolic and a tourist product (Bullock et al, 2018; Kizos and Vakoufaris, 2011). Olive oil is not strictly a product of the agro-food industry, but rather a socio-cultural and a symbolic product of the multidimensional bond of people and place. A product of century old and environmentallyfriendly methods, of special techniques and practices and a significant part of collective heritage, history, culture and identity. It is a unique value that cannot be produced "elsewhere" (Belletti and Marescotti, 2011; Anthopoulou, 2013).

The 'production for self-consumption' trend seems to aim at self-sustenance and was reported (by the respondents) to be characterized by natural methods of farming, satisfying health and quality reasons (e.g., fresh, locally-produced organic products without pesticides), taking into consideration safety issues in the agri-food chain and achievement of household food security (Knura et al, 2006; Inwood, et al, 2013; Van der Ploeg, 2013). Presently, the trend in Lesvos, and especially in our peri-urban case study area, is to produce olive oil for self-consumption from few (i.e., 4-5) trees and leave the rest of the olive crop uncollected. This trend is probably observed because our case study essentially regards landowners practicing farming, mostly on the side. The latter tend to sustain alternative sources of off-farm income and, as mentioned at the beginning of this section, practice self-consumption farming largely for health and cultural reasons - a basic characteristic of Lesvos family farming. Olive oil distributed to friends and relatives' and diaspora networks (often ensuring a small additional income) is an old practice embedded in local culture. Most such networks are informal. It provides a different marketing 
channel than the conventional ones and a distinct path to compete in the free market, since each farm household of the largest part of Lesvos produces its own olive oil.

\subsection{CAP subsidy schemes impact and characteristics}

CAP subsidy schemes provide low economic input, favouring larger farms and higher engagement in farming. In fact, the higher the landowners' engagement in farming, the higher the propensity to make use of this subsidy scheme.

However, the fact that the ecological value of olive farming areas of low-intensity with limited use of pesticides (also confirmed for Lesvos by other relevant surveys, i.e., Douma et al, 2016) provide habitats for many species of fauna and may, thus, sustain biodiversity, seems to be underestimated by policy planners, along with the trend that pesticides tend to be used more by landowners of larger farms. In this direction, the tendency for nitrogen use reduction may indicate that these landowners were better informed about the impacts of excessive use of nitrogen (than the ages below 40 years old) or that they are less profit oriented. Perennial crops and especially olive orchards, apart from economic and cultural services, provide a variety of ecosystem services such as maintenance of water and soil quality, fluid and erosion control, conservation of wildlife (Kantar et al, 2014; Torres-Miralles, 2017).

Motives for participation in CAP subsidy schemes were mainly economic. However, there were also some non-economic motives (ecological, social, cultural, and psychological) and most of the landowner-farmers who participated in such subsidy schemes were part-time and hobby farmers. In general, our findings indicate that motives for subsidy participation were more-thaneconomic and often regarded non-intensive, productive strategies and that there is a trend towards favouring larger farms and higher engagement in farming by such subsidy schemes. Motives for agri-environmental subsidy scheme participation were place-specific, adapted to differences in culture, agricultural systems, natural environments and landscapes, while hobby farmers - the dominant group of our study - and part-time farmers appeared to be influenced by a variety of types of motives. However, Mediterranean areas with marginal potential for agriculture tended to be less motivated to participate in agri-environmental subsidy schemes than farmers from Northern and Western European areas as previous survey showed (Pavlis et al, 2016). Thus, perhaps more emphasis ought to be given to such interrelated types of motives in the future, in association with economic and productive ones, considering more the local characteristics and the cultural value of peri-urban farming when planning future policy actions. Better access to information about such schemes and a reduction of bureaucracy may also improve future EU subsidy scheme uptake.

\subsection{Family farm sustainability}

In terms of family farm sustainability, there seem to be serious economic problems, since farm income appears to be very low similarly to previous research findings (Giourga et al, 2008) despite the 'friends and relative' channels of distribution (local and diaspora) and some other niche markets. The issue of sustainability is obviously not elaborated further in this study, since the latter is rather pertaining to issues pertaining to farm survival and not to a fully-blown assessment of local agricultural sustainability. As already mentioned, family farms of our case study seem to face some serious ecological issues such as the impact of climatic conditions and olive tree diseases that cause the olive grove to gradually lose its productivity. There are also issues regarding cultural sustainability of the olive grove since there is loss of cultural practices and olive heritage conservation after the spreading of the abandonment of the olive grove, especially in the uplands (Van der Sluis et al, 2014). This abandonment may lead to a series of cultural (i.e., identity loss, massive loss of terraces) and ecological problems (i.e., degradation, soil erosion). Such problems may cause a series of negative impacts, since there is still a strong dependence of local farmers-landowners on cultural factors and the farm is considered as a part of the local cultural landscape. Furthermore, there are also structural issues since farms are not market businesses and farmers cannot easily become entrepreneurs, while the number of farmers is decreasing. In addition, land segmentation in peri-urban and rural areas is very widespread in Greece, a trend that is confirmed by our study, since our random sample comprised 
of very small properties (less than $1 \mathrm{ha}$ ), a parameter which agricultural policies ought to take into consideration seriously, as this agricultural family holding regime has been one of the most significant and formative factors of postwar rural Greece up to date (Sivignon, 2008).

Burton et al (2008) refer to the need for culturally sustainable agri-environmental policy, providing farmers a sense of the cultural value of farming. In this line, it should also be taken into consideration the fact that peri-urban family farming is practiced mostly by landowners who deal with hobby and part-time farming. Although the farm households seem difficult to survive in a continuously demanding free market without using their competitive advantages. Van Vliet et al (2015) suggest the development of on-farm diversification (e.g., recreational services, direct sale of local niche products), combined with off-farm income, on the rationale that developed countries witness a long ongoing transition from 'agricultural economies' to 'service/knowledge economies' or 'community economies'. There are some new opportunities for the cooperative movement and for synergies with the increasing interest for social economy in Lesvos and some new scientific interest for the bioactivity of olive oil phenols, bio-economy, olive oil in perfume industry, etc.

\subsection{A decade after: assessing the respondents' perceptions on future farming and their landscape vision}

In order to supplement and update our research findings, in 2020, we returned and reviewed the trends revealed by our questionnaire survey, under present conditions. The repercussions and consequent austerity measures of the credit/financial crisis faced by Greece from 2008 to 2015 led the country to impoverishment and loss of income, and were immediately followed by the immigrant-refugee crisis (2015-2019) (Franck, 2018; Rozakou, 2019), when, according to UNHCR, there were 1.152.111 sea arrivals in the North Aegean Islands (mainly Chios, Samos and Lesvos) and most of them in Lesvos.

On the basis of personal and participant in-situ observation, the credit/financial crisis of 20082015, as expected, had adverse impacts (both direct and indirect) on the local economy and family farming in Lesvos. However, such impact was not as dire on Lesvos as in other parts of the country, such as the large urban centers (Artelaris, 2017) and has, therefore, not affected much the status quo on the island and, thus, the description of the situation and the findings of this research. Similarly, the immigrant-refugee crisis imparted serious social, political and economic impacts in the island as a whole and especially in the study area, but, it did not seem to affect long-standing farming conditions and rural landscape visions. During the immigrantrefugee crisis, there was not any hiring of asylum seekers or immigrants in rural activities, nor any attempt to address this crisis in sustainable development policies. The fact that farm laborers of lower technical skills tend to produce less (Grain, 2014) than more skilled ones is testified in our research findings, since this fact appears to be one of the reasons why local farmers-landowners tend not to hire immigrants (of the immigrant/ refugee crisis) in rural activities (many of them originating from countries with no such experience). Moreover, a distinct fact that ought to be mentioned is that a considerable part of the olive grove of Moria (part of the case study area) was chopped for timbering or destroyed after fires and immigrant/ refugee fighting in the Moria camp and surrounding area and, as a result, there has been no farming activity there, since 2015 . Local farmers-landowners have been staging complaints and claiming compensations for their agricultural losses, a demand that was partly fulfilled by the State. Up to this present day, there has been no landscape reformation plan for the devastated part of the Moria olive grove, even after the relocation of the camp to a new site in nearby Mavrovouni. In terms of farming engagement and activity, the number of part-time and hobby farmers, along with the productionfor-self-consumption trend (self-consumption agriculture) continue unabated.

Nonetheless, the period 2012-2021 was a period of some land use change, as expected. Between the time of our questionnaire survey (2012) and the years 2016 and 2018, when updated statistical data became available by the Hellenic Statistical Authority $(2016,2018)$, the total cultivated agricultural and fallow land seems to have been reduced by $26 \%$ from 2012 to 2018 , an indication of the abandonment of the uplands which had been predicted by the respondents. However, in the lowlands, there was no increase of vegetable cultivation as the respondents had suggested; rather, irrigated areas were reduced by $23 \%$ and that the number of trees and tree 
production for principal tree cultivations (orange, lemon, apple, mandarin, peer, cherry, fig, walnut, etc, trees) was much higher in 2012 (Hellenic Statistical Authority, 2018). Other cultivations did increase, in the same time period, and the area of some arable crops (cereals for grain) has almost trebled, along with several crops (e.g., fennel seed, cumin) and must, as vineyards were extended by almost $40 \%$. Edible pulse cultivation areas decreased by almost $30 \%$, along with melons, watermelons and potatoes, vegetables, and garden and horticulture areas, generally speaking, possibly signaling a trend towards cultivations that require less water.

In any case, the olive grove remains the dominant ecosystem on Lesvos and our case study area, but the latest available statistical data indicate that this crop yield is rather decreasing, as also indicated by our case study survey results. Accordingly, olive oil production appears to decrease gradually. Since 2013, when the production was 17,000 tones, the most productive year was 2018 with 11,400 tons, which stands in contrast with yields from previous years (20,000 tons in 2006; 26,500 tons in 2001 and 38,000 tons in 1999 (Hellenic Statistical Authority, 2018).

However, the other finding regarding the anticipated rise of the stock-breeding does not appear to be fulfilled, since such a trend was not confirmed by the latest statistics which show a $38 \%$ reduction in livestock numbers and $23 \%$ reduction in livestock units on Lesvos (Hellenic Statistical Authority, 2016). Thus, the stock-breeding increase found in our 2012 questionnaire survey might either be a distinct characteristic of the peri-urban area of Mytilini, or may have since been reversed.

In the same time period, some attempts were made towards the support of agricultural holdings and integrated agricultural systems management, such as the 'register of Agricultural Consultants' of ELGO-DIMITRA (Hellenic Agricultural Organization) in 2020, and the issuing of the Common Ministerial Decision for multi-functional farms (543/34450/2017). However, the State did not take any direct steps towards reinforcing agricultural education; in this field, only certain bottom-up cooperative initiatives (through seminars, meetings, etc.) were instigated during this period. Our survey respondents had predicted a rise in 'cooperation' in 2012; such a rise, indeed, materialized, whereby, since 2014, social economy actions have been taking place in Lesvos, with the Social Cooperative Enterprise "Modousa", as the most characteristic example. "Modousa" aims at overcoming some of the shortcomings of the status quo, such as the small size and fragmentation of agricultural holdings through cooperation, development of niche markets and the enhancement of locally-added value by branding and promoting territorial quality standards in conjunction with the local landscape. The social impact of "Modousa" has been evident through a series of activities, such as the organization of eco-festivals, musical and other events promoting local production and local arts and crafts, participation in and organization of information days and seminars, as well as, participation in research and consultancy projects, thematic working groups and competitions regarding rural issues. Other local innovative and collaborative networks of entrepreneurs have also developed clusters and synergies, in order to promote and establish their products in Greek and global markets (e.g., 'Lesvos Gourmet', 'Lesvos Food Fest', etc.). There have been no instances of private 'producers becoming traders' or of 'canceling the intermediaries'; the latter trends have only taken place, at a rather slow mode, through cooperatives.

Our 2012 survey answers on landscape visions, revealed an anticipated trend towards a more organized and mechanized agriculture. This trend was indeed observed, not in a way some respondents anticipated (e.g., widespread mechanization of olive harvest), but in the introduction of new irrigation systems of controlled water use (i.e., drop irrigation systems, self-propelled gunsprinkling units with injectors, horizontal irrigation ramps and self-propelled sprinkling units), honey extractors and modern milking machines with milk transfer lines, as well as other agricultural machinery such as pruning saws, harvesters and simple mowers (Hellenic Statistical Authority, 2018).

\subsection{Policy implications and proposals}

There is a need for new policies promoting cooperation between the farmers and ecological experts and better engagement of the farmer community (Zinngrebe et al, 2017), with an emphasis on synergies among farming, landscape, food, heritage and tourism ( $O$ ' Rourke et 
al, 2016; Gousios, 2013; Belletti and Marescotti, 2013). Pirro and Anguelovski (2017) pointed out the need for a stronger engagement among city councils and local communities, coordination of farmers, planners, managers, regulatory bodies, etc., co-dependent decision-making and common strategic vision for the management, planning and use of land. Furthermore, as Terkenli et al (2018) suggest the development of long-term strategies between local agriculture and tourism stakeholders by emphasizing the role of terraced landscapes in tourism, since Lesvos is 'a tourism destination still at the stage of discovery' (Terkenli et al, 2018:13). One way to succeed this is to build on the value of the olive grove as an ecomuseum combining small-scale tourism, olive culture, local manufacturing, and primary production sectors on the basis of an integrated tourism, environmental and agricultural policy (Pavlis, 2017). This means introduction of new olive products and by-products, development of home handicraft schemes, encouragement of knowledge exchange and agricultural education and in general synergies and cooperation among family farms, between farmers and ecological/landscape/food experts, city councils, local communities, planners, managers of local development, regulatory bodies and research institutes. One objective for the sustainable development of peri-urban family farming could be the development of an integrated policy for small-scale family farms based on a unified strategy and vision for the development of an "Aegean quality" agricultural brand. In this context, the application of EU and national policies specifically targeted to islands, such as the one of a reduced VAT regime (art. 120, Council Directive, 2006/112/EC) might be useful.

\section{Conclusions}

Our study shows that peri-urban family farming in Lesvos is characterized by a small-scale, traditional, low-profitability, low intensity and self-consumption-oriented family practice of high cultural value, run by landowners-farmers not economically dependent on farming, largely practicing hobby and part-time farming and lacking conventional agricultural education. Along with part-time farmers, hobby farmers seem to be the farmer group mostly practicing pluriactivity, propelled to participate in CAP subsidy schemes by a variety of more-than-economic types of motives-. A considerable quantity of olive oil not aimed for self-consumption is distributed via informal networks of 'friends and relatives' and diaspora, an old practice embedded in local culture. More recently, landowner-farmers of our case study area tend to harvest few olive trees, in order to ensure the 'family olive oil of the year', leaving the rest of the crop unharvested.

Overall, our findings show that peri-urban family farming has been practiced in both marginal and productive agricultural areas where the dominant (olive) crop yields have been decreasing (without a removal of olive trees) and other cultivations requiring less water have been increasing. As a result of all these processes and trends, local peri-urban family farms become trapped between the past and the future, embodying both tradition and modernization/ development, trends indelibly imprinted in the local cultural landscape. Peri-urban small family farming in Lesvos remains significant for land-property relationships, as a family asset, mainly because of cultural values embedded in local food culture and society. Conclusively, our research findings point to the need to build and expand on such values, through the development of new policies and longterm strategies, in order to overcome structural and economic problems impacting on family farm sustainability, to restructure local agricultural economy, and to promote more efficiently the qualities of Lesvos family farming.

\section{Acknowledgement}

This research was undertaken and partially funded in the context of EU FP7 research project on Visions of Land use Transitions in Europe (VOLANTE). 
[1] Adamopoulos, T. \& Restuccia, D. (2014). The Size Distribution of Farms and International Productivity Differences. American Economic Review 104(6), 1667-1697. DOI: 10.1257/aer.104.6.1667.

[2] Anthopoulou, T. (2013). Geographical indication and dynamics of territorial development in Greece. The difficult rise of collective action. In Anthopoulou, T., ed., On locality and particularity of foodstuffs: a territorial approach on rural development (pp. 255-279), Athens: Papazisi editions (in Greek).

[3] Arnalte-Alegre, E. \& Ortiz-Miranda, D. (2013). Chapter 3 The 'Southern Model' of European Agriculture Revisited: Continuities and Dynamics. In: Ortiz-Miranda, D., Moragues-Faus, A. \& Arnalte-Alegre, E., eds., Agriculture in Mediterranean Europe: Between Old and New Paradigms (pp. 37-74). Bingley: Emerald Group Publishing Limited. DOI: 10.1108/S10571922(2013)0000019005.

[4] Artelaris, P. (2017). Geographies of crisis in Greece: A social well-being approach, Geoforum 84, 59-69. DOI: 10.1016/j.geoforum.2017.06.003.

[5] Belletti, G. \& Marescotti, A. (2013). Typical agri-food products, local assets and sustainable development. In: Anthopoulou, T., ed., On locality and particularity of foodstuffs: a territorial approach on rural development (pp. 121-141). Athens: Papazisi editions (in Greek).

[6] Bullock, C., Joyce, D. \& Collier, M. (2018). An exploration of the relationships between cultural ecosystem services, socio-cultural values and wellbeing. Ecosystem Services 31(Part A), 42-152. DOI: 10.1016/j.ecoser.2018.02.020.

[7] Bunce, M. (1994). The countryside ideal: Anglo-American images of landscape, London: Routledge.

[8] Burton, R. J. F., Kuczera, C. \& Schwarz, G. (2008). Exploring Farmers' Cultural Resistance to Voluntary Agri-environmental Schemes. European Society for Rural Sociology 48(1), 1637. DOI: 10.1111/j.1467-9523.2008.00452.x.

[9] Ciria, C. S., Sanz, M., Carrasco, J. \& Ciria, P. (2019). Identification of Arable Marginal Lands under Rainfed Conditions for Bioenergy Purposes in Spain. Sustainability 11, Art. 1833. DOI: 10.3390/su11071833.

[10] Dadashpoor, H. \& Ahani, S. (2019). A conceptual typology of the spatial territories of the peripheral areas of metropolises, Habitat International 90, Art. 102015. DOI: 10.1016/j.habitatint.2019.102015.

[11] Damianakos, S. (2002). From the villager to the farmer. The Greek social society towards globalization. National Centre for Social Research (EKKE), Athens: Exandas Editions (in Greek).

[12] Debolini, M., Maraccini, E., Dubeuf, J. P., Geijzendorffer, I. R., Guerra, C., Simon, M., Targetti, S. \& Napoléone, C. (2018). Land and farming system dynamics and their drivers in the Mediterranean Basin. Land Use Policy 75, 702-710. DOI: 10.1016/j.landusepol.2017.07.010.

[13] De Longe, M. S., Miles, A. \& Carlisle, L. (2016). Investing in the transition to sustainable agriculture. Environmental Science \& Policy 55(1), 266-273. DOI: 10.1016/j.envsci.2015.09.013.

[14] De Rosa, M., McElwee, G. \& Smith, R. (2019). Farm diversification strategies in response to rural policy: a case from rural Italy. Land Use Policy 81, 291-301. DOI: 10.1016/j.landusepol.2018.11.006.

[15] Douma, C., Koutis, K., Thanopoulos, R., Tsigou, R., Galanidis, A. \& Bebeli, P. J. (2016). Diversity of agricultural plants on Lesvos Island (Northeast Aegean, Greece) with emphasis on fruit trees. Scientia Horticulturae 210, 65-84. DOI: 10.1016/j.scienta.2016.07.009. 
[16] Escribano, G. (2010). Convergence towards Differentiation: The case of Mediterranean energy corridors. Mediterranean Politics 15(2), 211-229. DOI: $10.1080 / 13629395.2010 .485048$.

[17] de Graaff, J. Zuazo, D. V-H., Jones, N., Fleskens, L. (2008). Olive production systems on sloping land: Prospects and scenarios. Journal of Environmental Management 89(2), 129 139. DOI: 10.1016/j.jenvman.2007.04.024.

[18] Franck, A. K (2018). The Lesvos Refugee Crisis as Disaster Capitalism. Peace Review 30(2), 199-205. DOI: 10.1080/10402659.2018.1458951.

[19] Galli, Fr., Moreno-Pérez., O., Adamsone-Fiskovica, A., Ortiz-Miranda, D., Pinto-Correia, T., Prosperi, P., Żmija, K., Brunori, G., Czekaj, M., Karanikolas, P., Bjorkhaug, H., Redman, M., Rivera, M., Sánchez-Zamora, P., Toma, I., Grando, St., Šūmane, S., Żmija, D., Eli Almaas, H., Duckett, D. (2020). How do small farms contribute to food and nutrition security? Linking small farms, strategies, outcomes in territorial food systems. Global Food Security 26, 100427. DOI: 10.1016/j.gfs.2020.100427.

[20] Gelfand, I., Sahajpal, R., Zhang, X., Izaurralde, R. C., Gross, K. L. \& Robertson, G. P. (2013). Sustainable bioenergy production from marginal lands in the US Midwest. Nature 493, 514 517. DOI: 10.1038/nature11811.

[21] Giourga, C., Loumou, A., Tsevreni, I. \& Vergou, A. (2008). Assessing the sustainability factors of traditional olive groves on Lesvos Island, Greece (Sustainability and traditional cultivation). GeoJournal 73, 149-159. DOI: 10.1007/s10708-008-9195-z.

[22] Gliessman, S. (2014). The International Year of Family Farming. Agroecology and Sustainable Food Systems 38(5), 503-504. DOI: 10.1080/21683565.2013.879977.

[23] Gliessman, S. (2015). Agroecology: A growing field. Agroecology and Sustainable Food Systems 39(1), 1-2. DOI: 10.1080/21683565.2014.965869.

[24] Gousios, D. (2013). A territorial approach of rural development. In: Anthopoulou, T. (ed.) On locality and particularity of foodstuffs: a territorial approach on rural development (pp. 72105). Athens: Papazisi editions (in Greek).

[25] Guiomar, N., Godinho, S., Pinto-Correia, T., Almeida, M., Bartolini, F., Bezák, P., Biró, M., Bjørkhaug, H., Bojnec, Š., Brunori, G., Corazzin, M., Czekaj, M., Davidova, S., Kania, J., Kristensen, S., Marraccini, E., Molnár, Zs., Niedermayr, J., O’ Rourke, E., Ortiz-Miranda, D., Redman, M., Sipiläinen, T., Sooväli-Sepping, H., Šūmane, S., Surová, D., Sutherland, L. A., Tcherkezova, E., Tisenkopfs, T., Tsiligiridis, T, Tudor, M. M., Wagner, K., Wästfelt, A. (2018). Typology and distribution of small farms in Europe: Towards a better picture. Land Use Policy 75, 784-798. DOI: 10.1016/j.landusepol.2018.04.012.

[26] Hubbard, C. (2009). Small Farms in the EU: How Small is Small? [unpublished conference paper]. Canterbury: European Association of Agricultural Economists. DOI: 10.22004/ag.econ.52852.

[27] Hennessy, T. (2014). CAP 2014-2020 tools to enhance family farming: opportunities and limits. Brussels: European Parliament.

[28] Hopkins, J. (1998). Signs of the post-rural: marketing myths of a symbolic countryside. Geografiska Annaler 80B, 65-81.

[29] Ingram, J., Gaskell, P., Mills, J. \& Short, C. (2013). Incorporating agri-environment schemes into farm development pathways: A temporal analysis of farmer motivations. Land Use Policy 31, 267-279. DOI: 10.1016/j.landusepol.2012.07.007.

[30] Inwood, S., Clark, J. K. \& Bean, M. (2013). The differing values of multigeneration and firstgeneration farmers: their influence on the structure of agriculture at the rural-urban interface. Rural Sociology 78(3), 346-370. DOI: 10.1111/ruso.12012.

[31] Kantar, M. B., Betts, K., Michno, J.-M.S., Luby, J. J., Morrell, P. \& Hulke, B. S. (2014). Evaluating an interspecific Helianthus annuus $x$ Helianthus tuberosus population for use in 
a perennial sunflower breeding program. Field Crops Research 155, 254-264. DOI: $10.1016 / j . f c r .2013 .04 .018$.

[32] Karanikolas, P. \& Zografakis, S. (2008). Greek farm households: income inequality, poverty and distributional impact of farm income. Social Cohesion and Development 3(1), 27-44. DOI: $10.12681 /$ scad.8898.

[33] Kasimis, C. \& Papadopoulos, A. (2013). Chapter 11: Rural transformations and family farming in contemporary Greece. In: Ortiz-Miranda, D., Moragues-Faus, A. \& Arnalte-Alegre, E., eds., Agriculture in Mediterranean Europe: Between Old and New Paradigms (pp. 263293). Bingley: Emerald Group Publishing Limited. DOI: 10.1108/S10571922(2013)0000019013.

[34] Kizos, T. \& Koulouri, M. (2006). Agricultural landscape dynamics in the Mediterranean: Lesvos (Greece) case study using evidence from the last three centuries. Environmental Science and Policy 9(4), 330-342. DOI: 10.1016/j.envisci.2006.02.002.

[35] Kizos, T. \& Vakoufaris, H. (2011). Valorisation of a local asset: The case of olive oil on Lesvos Island, Greece. Food Policy 36, 704-713. DOI: 10.1016/j.foodpol.2011.06.005.

[36] Knura, S., Gymnich, S, Rembialkowska, E. \& Petersen, B. (2006). Agri-food production chain. In: Luning, P., Devlieghere, F. \& Verhé, R., eds., Safety in the agri-food chain (pp. 1965). Wageningen: Wageningen Academic Publishers.

[37] Koutsou, S., Partalidou, M. \& Petrou, M. (2011). Present or absent farm heads? A contemporary reading of family farming in Greece. Sociologia Ruralis 51(4), 404-419. DOI: 10.1111/j.1467-9523.2011.00541.x.

[38] Kristensen, S. B. P, Busck, A. G., van der Sluis, T. \& Gaube, V. (2015). Patterns and drivers of land use change in selected European rural landscapes. Land Use Policy 57, 786-799. DOI: 10.1016/j.landusepol.2015.07.014.

[39] Luttik, J. \& Van der Ploeg, B. (2004). Functions of agriculture in urban society in the Netherlands. In Brouwer, F., ed., Sustaining Agriculture and the Rural Economy: Governance, Policy and Multifunctionality (pp. 204-222). Cheltenham: Edward Elgar.

[40] Lowder, S. K., Skoet, J. \& Raney, T. (2016). The Number, Size, and Distribution of Farms, Smallholder Farms, and Family Farms Worldwide. World Development 87, 16-29. DOI: 10.1016/j.worlddev.2015.10.041.

[41] Nitsiakos, V. G. (1991). Traditional social structures, Athens: Odysseus (in Greek).

[42] Ortiz-Miranda, D., Moragues-Faus, A., Arnalte-Alegre, E. (2013). Chapter 12: Agriculture in Mediterranean Europe: Challenging Theory and Policy. In: Ortiz-Miranda, L., MoraguesFaus, D. \& Arnalte-Alegre, E., eds., Agriculture in Mediterranean Europe: Between Old and New Paradigms (pp. 295-310). Bingley: Emerald Group Publishing Limited.

[43] O'Rourke, E., Charbonneau, M. \& Poinsot, Y. (2016). High Nature Value mountain farming systems in Europe: case studies from the Atlantic Pyrenees, France and the Kerry Uplands. Journal of Rural Studies 46, 47-59. DOI: 10.1016/j.jrurstud.2016.05.010.

[44] Palang, H., Soini, S., Printsmann, A. \& Birkeland, I. (2017). Landscape and cultural $\begin{array}{llll}\text { sustainability. Norsk } \quad \text { Geografisk } & \text { 127-131. }\end{array}$ DOI: 10.1080/00291951.2017.1343381.

[45] Park, C. \& Coppack, P. M. (1994). The role of rural sentiment and vernacular landscapes in contriving sense of place in the city's countryside. Geografiska Annaler 76B(3), 161-172. DOI: 10.1080/04353684.1994.11879673.

[46] Pavlis, E. (2017). North Aegean island landscapes as ecomuseums: the case of Lesvos Island. Island Studies Journal 12(1), 135-150. DOI: 10.24043/ISJ.9.

[47] Pavlis, E., Terkenli, T. S., Kristensen, S. B. P., Busck, A. G. \& Cosor, G. (2016). Patterns of Agri-Environmental Scheme Participation in Europe: Indicative Trends from Selected Case Studies. Land Use Policy 57, 800-812. DOI: 10.1016/j.landusepol.2015.09.024. 
[48] Peters, R. (2013). Family Farming. EU Rural Review 17. Brussels: European Network for Rural Development.

[49] Pirro, C. \& Anguelovski, I. (2017). Farming the urban fringes of Barcelona: Competing visions of nature and the contestation of a partial sustainability fix. Geoforum 82, 53-65. DOI: 10.1016/j.geoforum.2017.03.023.

[50] Rivera, M., Guarín, Al., Pinto-Correia, T., Almaas, H., Arnalte Mur, L., Burns, V., Czekaj, M., Ellis, R., Galli, Fr., Grivins, M., Hernández, P., Karanikolas, P., Prosperi, P. \& Sánchez Zamora, P. (2020). Assessing the role of European small farms in regional food systems: insights from a territorial approach. Global Food Security 26, Art. 100417. DOI: 10.1016/j.gfs.2020.100417.

[51] Rozakou, K. (2019). 'How did you get in?' Research access and sovereign power during the 'migration crisis' in Greece. Social Anthropology/Anthropologie Sociale 27, 68-83. DOI: 10.1111/1469-8676.12620.

[52] Russo, P., Tomaselli, G. \& Pappalardo, G. (2014). Marginal peri-urban agricultural areas: A support method for landscape planning. Land Use Policy 41, 97-109. DOI: 10.1016/j.landusepol.2014.04.017.

[53] Sivignon, M. (2008). The Greek agricultural holdings from Konstantino Karavida to Stathis Damianakos: The approach of a geographer. In Zakopoulou, E., Kasimis, H, Louloudis, L., eds., Rurality, Society and Space (pp. 81-92). Athens: Plethron.

[54] Soini, K. \& Dessein, J. (2016). Culture-Sustainability Relation: Towards a Conceptual Framework. Sustainability 8(2), Art. 167. DOI: 10.3390/su8020167.

[55] Terkenli, T. S., Cisani, M. \& Castiglioni, B. (2018). Is There a Future for Tourism in Terraced Landscapes? A Comparative Study of Landscape Resources and Tourism Consequences in Valtellina (Italy) and Lesvos (Greece). Series Historia et Sociologia 28(4), 725-740.

[56] Torres-Miralles, M., Grammatikopoulou, I. \& Rescia, A. J. (2017). Employing contingent and inferred valuation methods to evaluate the conservation of olive groves and associated ecosystem services in Andalusia (Spain). Ecosystem Services 26A, 258-269. DOI: 10.1016/j.ecoser.2017.07.002.

[57] Van der Ploeg, J. D. (2008). On Rurality, Rural Development and Rural Sociology. In van Santen, J., ed., Development in Place: Perspectives and Challenges (pp. 39-73). Amsterdam: Aksant.

[58] Van der Ploeg, J. D. (2013). Ten qualities of family farming. Farming Matters 29(4), 8-11.

[59] Van der Ploeg, J. D. (2016). Family farming in Europe and Central Asia: history, characteristics, threats and potentials [Working paper number 153]. Roma: Food and Agriculture Organization of the United Nations and the International Policy Centre for Inclusive Growth of the United Nations Development Programme.

[60] Van der Sluis, T., Pedroli, B. \& Kizos, T. (2014). Landscape change in Mediterranean farmlands: impacts of land abandonment on cultivation terraces in Portofino (Italy) and Lesvos (Greece). Journal of Landscape Ecology 7(1), 23-44. DOI: 10.2478/jlecol-20140008.

[61] Van der Sluis, T., Pedroli, B., Kristensen, S., Cosor, G. \& Pavlis, E. (2016). Changing land use intensity in Europe - Recent processes in selected case studies. Land Use Policy 57, 777-785. DOI: 10.1016/j.landusepol.2014.12.005.

[62] Van Vliet, J. A., Schut, A. G. T., Reidsma, P., Descheemaeker, K., Slingerland, M. \& van de Ven, G. W. J. (2015). De-mystifying family farming: Features, diversity and trends across the globe. Global Food Security 5, 11-18. DOI: 10.1016/j.gfs.2015.03.001.

[63] Vesterager, J. P., Frederiksen, P., Busck, A. G., Terkenli, T., Pavlis, V., Van der Sluis, T., Geamana, N., Bucur, M., Vadineanu, A., Kristensen, S. B. P. \& Gaube, V. (2016). Dynamics 
in National Agri-environmental Policy implementation under Changing EU Policy Priorities: does one size fit all? Land Use Policy 57, 764-776. DOI: 10.1016/j.landusepol.2015.05.014.

[64] Vlahos, G. \& Louloudis, L. (2011). Landscape and agriculture under the reformed Common Agricultural Policy in Greece: Constructing a typology of interventions. Geografisk TidsskriftDanish Journal of Geography 111(2), 131-147. DOI: 10.1080/00167223.2011.10669529.

[65] Wolf, J., Kanellopoulos, A., Kros, J., Webber, H., Zhao, G., Britz, W. \& de Vries, W. (2015). Combined analysis of climate, technological and price changes on future arable farming systems in Europe. Agricultural Systems 140, 5673. DOI: 10.1016/j.agsy.2015.08.010.

[66] Zakopoulou, E. (2008). The triumph of the farmer. The aspect of Stathis Damianakis for the rurality of the Modern Greek society. In Zakopoulou, E. Kasimis, C. \& Louloudis, L., eds., Rurality, Society, Space (pp. 27-38). Athens: Plethron edition (in Greek).

[67] Zasada, I. (2011). Multifunctional peri-urban agriculture-A review of societal demands and the provision of goods and services. Land Use Policy 28(4), 639-648. DOI: 10.1016/j.landusepol.2011.01.008.

[68] Zasada, I., Weltin, M., Reutter, M., Verburg, P. H. \& Piorr, A. (2018). EU's rural development policy at the regional level-Are expenditures for natural capital linked with territorial needs? Land Use Policy 77, 344-353. DOI: 10.1016/j.landusepol.2018.05.053.

[69] Zinngrebe, Y., Pe'er, G., Schüler, S., Schmitt, J., Schmidt, J. \& Lakner, S. (2017). The EU's Ecological Focus Areas - explaining farmers' choices in Germany. Land Use Policy 65, 93108. DOI: 10.1016/j.landusepol.2017.03.027.

Other sources

[70] Agriculture, forestry and fishery statistics (2013). Luxembourg: EUROSTAT. http://epp.eurostat.ec.europa.eu/cache/ITY_OFFPUB/KS-FK-13-001/EN/KS-FK-13-001EN.PDF.

[71] Economic characteristics by region 2011 and 2001 (2014). Athens: Hellenic Statistical Authority http://www.statistics.gr/el/statistics/-/publication/SAM04/-

[72] Ending poverty and hunger by investing in agriculture and rural areas (2014). Rome: FAO (Food and Agriculture Organization of the United Nations) (2014b) http://www.fao.org/3/ai7556e.pdf.

[73] Grain (2014). Report "Hungry for Land". https://grain.org/article/entries/4929-hungry-forland-small-farmers-feed-the-world-with-less-than-a-quarter-of-all-farmland.

[74] Islands' Atlas, The Development of the Islands - European Islands and Cohesion Policy (EUROISLANDS), Mytilini: University of the Aegean.

[75] Mylonas, P. (2015). Olive Oil: Establishing the Greek brand [Sectoral Report], Athens: National Bank of Greece.

[76] Operation portal. Refugee situation. Geneve: UNHCR, https://www.unhcr.org/ https://data2.unhcr.org/en/situations/mediterranean/location/5179 (Retrieved at 7.3.2021).

[77] Rural development and the future of small-scale family farms (2015) Rome: FAO (Food and Agriculture Organization of the United Nations). http://www.fao.org/3/a-i5153e.pdf.

[78] The State of Food and Agriculture: Innovation in family farming (2014). Rome: FAO (Food and Agriculture Organization of the United Nations) (2014a). http://www.fao.org/3/ai4040e.pdf. 